medRxiv preprint doi: https://doi.org/10.1101/2020.05.29.20116665; this version posted June 17, 2020. The copyright holder for this preprint (which was not certified by peer review) is the author/funder, who has granted medRxiv a license to display the preprint in perpetuity.

It is made available under a CC-BY-NC 4.0 International license .

\title{
Risk factors of coronary microvascular obstruction
}

Yong $\mathrm{Li}^{1}$ and Shuzheng Lyu ${ }^{2}$

${ }^{1}$ Emergency and Critical Care Center, Beijing Anzhen Hospital,Capital Medical University

, Beijing 100029, China

${ }^{2}$ Department of Cardiology, Beijing Anzhen Hospital,Capital Medical University, Beijing 100029, China.

Correspondence should be addressed to Yong Li; liyongdoctor@sina.com and Shuzheng Lyu; shuzheng023@163.com.

\section{Abstract}

Background. Coronary microvascular obstruction /no-reflow(CMVO/NR) is a predictor of longterm mortality in survivors of ST elevation myocardial infarction (STEMI) underwent primary percutaneous coronary intervention (PPCI). Objective. To identify risk factors of CMVO/NR during PPCI. Methods. Totally 2384 STEMI patients treated with PPCI were divided into two groups according to thrombolysis in myocardial infarction(TIMI) flow grade:CMVO/NR group(246cases,TIMI 0-2 grade) and control group(2138 cases,TIMI 3 grade). We used univariable and multivariable logistic regression to identify risk factors of CMVO/NR during PPCI. Results. A frequency of CMVO/NR was $10.3 \%(246 / 2384)$. Logistic regression analysis showed that the differences between the two groups in age(unadjusted odds ratios [OR] 1.032; 95\% CI, 1.02 to 1.045 ; adjusted OR $1.032 ; 95 \% \mathrm{CI}, 1.02$ to $1.046 ; \mathrm{P}<0.001$ ), periprocedural bradycardia (unadjusted OR 2.357 ; 95\% CI, 1.752 to 3.171; adjusted OR1.818; 95\% CI, 1.338 to 2.471 ; $\mathrm{P}<0.001$ ), using thrombus aspiration devices during operation (unadjusted OR 2.489 ; 95\% CI, 1.815 to 3.414 ; adjusted OR1.835; 95\% CI, 1.291 to 2.606 ; P =0.001),neutrophil percentage (unadjusted OR 1.028 ; $95 \%$ CI, 1.014 to 1.042 ; adjusted OR1.022; 95\% CI, 1.008 to $1.036 ; \mathrm{P}=0.002$ ), and total occlusion of the culprit vessel (unadjusted OR 2.626;95\% CI, 1.85 to 3.728 ; adjusted-OR $1.656 ; 95 \% \mathrm{CI}, 1.119$ to $2.45 ; \mathrm{P}=0.012$ ) were statistically significant $(\mathrm{P}<0$. 
medRxiv preprint doi: https://doi.org/10.1101/2020.05.29.20116665; this version posted June 17, 2020. The copyright holder for this preprint (which was not certified by peer review) is the author/funder, who has granted medRxiv a license to display the preprint in perpetuity.

It is made available under a CC-BY-NC 4.0 International license .

05). The area under the receiver operating characteristic curve was 0.6896 .Conclusions. Age,periprocedural bradycardia, using thrombus aspiration devices during operation, neutrophil percentage , and total occlusion of the culprit vessel may be independent risk factors for predicting CMVO/NR during PPCI.

We registered this study with WHO International Clinical Trials Registry Platform (ICTRP) (registration number: ChiCTR1900023213; registered date: 16 May 2019).http://www.chictr.org.cn/edit.aspx?pid=39057\&htm=4.

Key Words: Coronary disease ST elevation myocardial infarction No-reflow phenomenon Percutaneous coronary intervention

\section{Background}

Coronary microvascular obstruction /no-reflow(CMVO/NR) is a predictor of long-term mortality in survivors of ST elevation myocardial infarction (STEMI)underwent primary percutaneous coronary intervention (PPCI). ${ }^{[1-4]} \mathrm{CMVO} / \mathrm{NR}$ is defined as inadequate myocardial perfusion after successful mechanical opening of the infarct-related artery. ${ }^{[1,4,5]} \mathrm{CMVO} / \mathrm{NR}$ is diagnosed immediately after PCI when postprocedural angiographic thrombolysis in myocardial infarction(TIMI) flow is $<3$, or in the case of a TIMI flow of 3 when myocardial blush grade is 0 or 1, or when ST resolution within 60-90 $\mathrm{min}$ of the procedure is $<70 \% .^{[4,5]}$ There have been few large clinical trials of therapies, specifically aimed at reducing CMVO/NR. ${ }^{[1,6]}$ Prevention of CMVO/NR is a crucial step. We want to identify risk factors of CMVO/NR during PPCI.

\section{Methods}

Totally 2384 STEMI patients who were consecutively treated with PPCI in Beijing Anzhen Hospital, Capital Medical University between 2007 and 2018.

Prior to emergency angiography, all patients received $300 \mathrm{mg}$ of aspirin, 300 to $600 \mathrm{mg}$ of clopidogrel or $180 \mathrm{mg}$ of ticagrelor and unfractionated heparin. 
medRxiv preprint doi: https://doi.org/10.1101/2020.05.29.20116665; this version posted June 17, 2020. The copyright holder for this preprint (which was not certified by peer review) is the author/funder, who has granted medRxiv a license to display the preprint in perpetuity.

It is made available under a CC-BY-NC 4.0 International license.

Inclusion criteria: STEMI patients presenting within 12 hours from the symptom onset who were treated with PPCI . We established the diagnosis of acute myocardial infarction (AMI) and STEMI base on fourth universal definition of myocardial infarction . ${ }^{[7]}$

Exclusion criteria. 1. patients received thrombolysis; 2. patients received bivalirudin.

$\mathrm{CMVO} / \mathrm{NR}$ was defined as TIMI <3 after successful mechanical opening of the infarct-related arterie with a guide wire, a balloon, or a stent, not the end of the PPCI process. ${ }^{[4]}{ }^{[5]}$

We selected 15 predictors based on clinical relevance and the results of the pre-experiment cohort.

They were shown in Table 1. Periprocedural bradycardia was defined as preoperative heart rate $\geq$ 50 times / min, intraoperative heart rate $<50$ times / min persistent or transient. ${ }^{[8]}$ Intra-procedural hypotension was defined as pre-procedural systolic blood pressure was $>90 \mathrm{mmHg}$, intraprocedural systolic blood pressure less than or equal to $90 \mathrm{mmHg}$ persistent or transient. ${ }^{[9]}$ Whether a thrombus aspiration device was used depends on interventionalist.

\section{Statistical analysis.}

We followed the methods of $\mathrm{Li}$ et al. 2019. ${ }^{[10]}$ We constructed a multivariable logistic regression model using the backward variable selection method.Statistical analyses were performed with STATA version 15.1 .P value <0.05 was considered statistically significant.

\section{Results}

During PPCI procedure, 2138 patients had a TIMI flow grade 3 (group with normal epicardial flow) and 246patients had a TIMI flow grade 0 2 (group with CMVO/NR). Baseline characteristics of the patients were shown in Table 1 . We used univariable and multivariable logistic regression to identify predictors of CMVO/NR. We identified 10 variables (age, sex ,total occlusion of the culprit vessel, periprocedural bradycardia, intra-procedural hypotension,using thrombus aspiration devices during operation, neutrophil percentage, hemoglobin, the time between myocardial infarction and PPCI, and the culprit vessel was left circumflex) as predictors of CMVO/NR in univariable analysis. Five variables ( age, periprocedural bradycardia, using thrombus aspiration devices during 
medRxiv preprint doi: https://doi.org/10.1101/2020.05.29.20116665; this version posted June 17, 2020. The copyright holder for this preprint (which was not certified by peer review) is the author/funder, who has granted medRxiv a license to display the preprint in perpetuity.

It is made available under a CC-BY-NC 4.0 International license .

operation, neutrophil percentage, and total occlusion of the culprit vessel) remained as independent predictors of CMVO/NR in multivariable analysis. The results were shown in Table 2 and Table3.

The receiver operating characteristic curve was drawn.The area under the receiver operating characteristic curve was $0.6896 \pm 0.017,95 \% \mathrm{CI}=0.656 \sim 0.723$.

\section{Discussion}

$\mathrm{CMVO} / \mathrm{NR}$ is a multifactorial phenomenon and five mechanisms have been recognized : (i) preexisting microvascular dysfunction, (ii) distal microthrombo-embolization, (iii) ischemic injury, (iv) reperfusion injury and (v) individual susceptibility. ${ }^{[5]}$ In our study, age , periprocedural bradycardia, using thrombus aspiration devices during operation, neutrophil percentage, and total occlusion of the culprit vessel are associated with an increased risk of CMVO/NR.

Advanced age has been reported to be an independent risk factor of CMVO/NR. ${ }^{[5]}$ Previous studies had shown that abnormal non-endothelium-dependent microvasodilation appears to be related to functional and structural changes that lead to impaired coronary blood flow reserve with aging. ${ }^{[5]}$

Periprocedural bradycardia may be a sign of CMVO/NR. ${ }^{[10]}$ In our study, patients with periprocedural bradycardia were at 1.82 higher risk of CMVO/NR than patients without periprocedural bradycardia. Myocardial reperfusion can evoke activation of Bezold-Jarisch reflex. ${ }^{[11]}$ The Bezold-Jarisch reflex means bradycardia, vasodilation, and hypotension.

${ }^{[12]}$ Acetylcholine, which is endothelium-dependent vasodilator, induces coronary dilation in young healthy subjects but cause vasoconstriction in patients with atherosclerosis. ${ }^{[10]}$ Excessive vagus nerve excitation is an important factor that may cause CMVO/NR. We should inhibit it to prevent and treat $\mathrm{CMVO} / \mathrm{NR}$.

Total occlusion of the culprit vessel is a independent risk factor of CMVO/NR. ${ }^{[13]}$ In our study, patients with total occlusion of culprit vessel were at 1.66 higher risk of CMVO/NR than patients 
medRxiv preprint doi: https://doi.org/10.1101/2020.05.29.20116665; this version posted June 17, 2020. The copyright holder for this preprint

(which was not certified by peer review) is the author/funder, who has granted medRxiv a license to display the preprint in perpetuity.

It is made available under a CC-BY-NC 4.0 International license .

without total occlusion of the culprit vessel. Good patency of the infarct-related artery prior to PPCI

suggests lower thrombus burden and so on. ${ }^{[14]}$

Neutrophil percentage is an independent risk factor for CMVO/NR. Neutrophil plugging plays a role in the pathogenesis of CMVO/NR. A massive infiltration of microcirculation by neutrophils occurs at the time of reperfusion. ${ }^{[15]}$ Activated neutrophils release reactive oxygen species and proinflammatory molecules, which can contribute to CMVO/NR. ${ }^{[15]}$

Using thrombus aspiration device during PCI is closely related to CMVO/NR. Routine thrombus aspiration is not recommended, but in cases of large residual thrombus burden after opening the vessel with a guide wire or a balloon, thrombus aspiration may be considered. ${ }^{[4]}$ When the thrombus load is high, the thrombus aspiration device tends to be used while CMVO/NR tends to occur.

\section{Study Limitations}

This is a single center experience. Some patients were enrolled $>10$ years ago thus their treatment may not conform to current standards and techniques. Only TIMI flow grade was used to identify $\mathrm{CMVO} / \mathrm{NR}$, and no other diagnostic methods were used because of limited data. We want to get risk factors of CMVO/NR before it happen, some variables associated with $\mathrm{CMVO} / \mathrm{NR}$ was not including, so the area under the receiver operating characteristic curve was not strong enough.

\section{Conclusions}

Age,periprocedural bradycardia,using thrombus aspiration devices during operation,neutrophil percentage, and total occlusion of the culprit vessel may be independent risk factors for predicting CMVO/NR during PPCI.

\section{List of abbreviations}


AMI: $\quad$ Acute myocardial infarction

CMVO Coronary microvascular obstruction

NR No-reflow

PCI: $\quad$ Percutaneous coronary intervention

PPCI: Primary percutaneous coronary intervention

STEMI: $\quad$ ST elevation myocardial infarction

TIMI: $\quad$ Trombolysis in myocardial infarction risk score

\section{Declarations}

\section{Ethics approval and consent to participate}

Ethic committee approved the study. Approved No. of ethic committee: 2019013X.

Name of the ethic committee : Ethics committee of Beijing Anzhen Hospital Capital Medical

University.It was a retrospective analysis and informed consent was waived by Ethics Committee of

Beijing Anzhen Hospital Capital Medical University.

\section{Statement of human and animal rights}

All procedures performed in studies involving human participants were in accordance with the ethical standards of the institutional and/or national research committee and with the 1964 Helsinki declaration and its later amendments or comparable ethical standards. The study was not conducted with animals.

\section{Consent for publication}

Not applicable.

\section{Availability of data and materials}


The data used to support the findings of this study are included within the supplementary information file.

The data are demographic, clinical, and angiographic characteristics of patients with acute STEMI during PPCI. $\mathrm{AH}=$ History of angina; $\mathrm{AGE}=$ age; TOCV=total occlusion of the culprit vessel; $\mathrm{CNR}=\mathrm{CMVO} / \mathrm{NR} ; \mathrm{DH}=$ history of diabetes; $\mathrm{H}=$ hemoglobin $; \mathrm{HH}=$ history of hypertension; $\mathrm{IH}=$ introperative hypotension ; $\mathrm{LAD}=$ the culprit vessel was left anterior descending coronary artery; $\mathrm{LCX}=$ the culprit vessel was left circumflex coronary artery ;MIH=history of myocardial infarction; $\mathrm{NP}=$ neutrophil percentage; $\mathrm{PB}=$ periprocedural bradycardia; $\mathrm{PCIH}=$ history of percutaneous coronary intervention; $\mathrm{RCA}=$ the culprit vessel was right coronary artery $; \mathrm{S}=$ sex; $\mathrm{TA}=\mathrm{using}$ thrombus aspirationdevices during operation; TBMIPPCI =the time between myocardial infarction and PPCI.

\section{Competing interests}

The authors declare that they have no conflicts of interest.

\section{Funding}

None.

\section{Authors' contributions}

Yong Li contributed to generating, analysing, and interpreting the study data and drafted the manuscript. Shuzheng Lyu contributed to planning and revised the manuscript critically for important intellectual content. Yong Li and Shuzheng Lyu are responsible for the overall content as guarantor. All authors have read and approved the manuscript.

\section{Acknowledgements}

None. 
medRxiv preprint doi: https://doi.org/10.1101/2020.05.29.20116665; this version posted June 17, 2020. The copyright holder for this preprint (which was not certified by peer review) is the author/funder, who has granted medRxiv a license to display the preprint in perpetuity.

It is made available under a CC-BY-NC 4.0 International license .

Table 1. Demographic,clinical,and angiographic characteristics of patients with CMVO/NR and normal coronary flow during PPCI

\begin{tabular}{lccccc}
\hline Characteristic & Total & Normal & & Odds \\
[lower limit, upper limit] & $(\mathrm{n}=2384)$ & CMVO/NR & Flow & $\mathrm{P}>|\mathrm{Z}|$ & Ratio \\
& & $(\mathrm{n}=246)$ & & & \\
\end{tabular}

Age(year,X \pm s) $[23,80]$

$57 \pm 11$

$60 \pm 11$

$56 \pm 11$

$<0.001$

1.032

$1.02 \sim 1.045$

Man n(\%)

History of hypertension $n(\%)$

History of diabetes $\mathrm{n}(\%)$

History of angina $\mathrm{n}(\%)$

History of myocardial

infarction $\mathrm{n}(\%)$

History of PCI n(\%)

Culprit vessel site n(\%)

Left anterior descending

Left circumflex $\begin{array}{llllll}617(25.9) & 71(28.9) & 546(25.5) & 0.26 & 1.183 & .883 \sim 1.585\end{array}$

$\begin{array}{llllll}1093(45.8) & 105(42.7) & 988(46.2) & 0.293 & .867 & .664 \sim 1.132\end{array}$

$\begin{array}{llllll}190(7.9) & 21(8.5) & 169(7.9) & 0.729 & 1.087 & .677 \sim 1.747\end{array}$

$\begin{array}{llllll}230(9.6) & 27(11) & 203(9.5) & 0.457 & 1.175 & .768 \sim 1.798\end{array}$

$\begin{array}{llllll}278(11.7) & 19(7.7) & 259(12.1) & 0.044 & .607 & .374 \sim .987\end{array}$ 
medRxiv preprint doi: https://doi.org/10.1101/2020.05.29.20116665; this version posted June 17, 2020. The copyright holder for this preprint (which was not certified by peer review) is the author/funder, who has granted medRxiv a license to display the preprint in perpetuity.

It is made available under a CC-BY-NC 4.0 International license .

Right coronary artery

$$
\begin{array}{llllll}
961(40.3) & 113(45.9) & 848(39.7) & 0.058 & 1.292 & .991 \sim 1.685
\end{array}
$$

Total occlusion of the culprit

vessel $\mathrm{n}(\%)$

$1622(68)$

206(83.7)

$1416(66.2)$

$<0.001$

2.626

$1.85 \sim 3.728$

Using thrombus aspiration devices

during operation $\mathrm{n}(\%)$

1463(61.4)

$193(78.5)$

$1270(59.4)<0.001$

$2.489 \quad 1.815 \sim 3.414$

Periprocedural bradycardia n(\%)

$$
\begin{array}{llllll}
404(16.9) & 74(30.1) & 330(15.4) & <0.001 & 2.357 & 1.752 \sim 3.171
\end{array}
$$

Intra-procedural hypotension $\mathrm{n}(\%)$

$225(9.4)$

$40(16.3)$

$185(8.7)$

$<0.001$

2.05

$1.415 \sim 2.97$

The time between myocardial

infarction and PPCI (min, $\mathrm{x} \pm \mathrm{s}) \quad 334 \pm 155$

$354 \pm 153 \quad 332 \pm 156 \quad 0.039$

$1.001 \quad$ 1. $\sim 1.002$

$[60,720]$

Neutrophil percentage

$(\%, \mathrm{X} \pm \mathrm{s})[27.8,95.4]$

$77 \pm 12$

$80 \pm 10$

$77 \pm 12$

$<0.001$

1.028

$1.014 \sim 1.042$

$\operatorname{Hemoglobin}(\mathrm{g} / \mathrm{l}, \mathrm{x} \pm \mathrm{s})[69,208]$

$\begin{array}{llllll}147 \pm 16 & 145 \pm 16 & 148 \pm 16 & 0.003 & .988 & .98 \sim .996\end{array}$

Table 2. Predictor of CMVO/NR obtained from multivariable logistic regression models ( odds ratio )

\begin{tabular}{lllllr}
\hline CMVO/NR & Odds ratio & Std.Err & $\mathrm{Z}$ & $\mathrm{P}>|\mathrm{Z}|$ & $95 \% \mathrm{CI}$ \\
\hline Age & 1.032 & .007 & 4.96 & $<0.001$ & $1.02 \sim 1.045$ \\
Periprocedural & & & & & \\
bradycardia & 1.818 & .285 & 3.82 & $<0.001$ & $1.338 \sim 2.471$ \\
Using thrombus & & & & & \\
aspiration devices & 1.835 & .329 & 3.39 & 0.001 & $1.291 \sim 2.606$ \\
during operation & & & & &
\end{tabular}


medRxiv preprint doi: https://doi.org/10.1101/2020.05.29.20116665; this version posted June 17, 2020. The copyright holder for this preprint (which was not certified by peer review) is the author/funder, who has granted medRxiv a license to display the preprint in perpetuity.

It is made available under a CC-BY-NC 4.0 International license .

$\begin{array}{lccccc}\text { Total occlusion of the } & 1.656 & .331 & 2.52 & 0.012 & 1.119 \sim 2.45 \\ \begin{array}{l}\text { culprit vessel } \\ \text { Neutrophil percentage }\end{array} & 1.022 & 0.007 & 3.14 & 0.002 & 1.008 \sim 1.036 \\ & .001 & .001 & -9.64 & <0.001 & .0003 \sim .005\end{array}$

Table 3. Predictor of CMVO/NR obtained from multivariable logistic regression models ( Coef )

\begin{tabular}{llllll}
\hline CMVO/NR & Coef & Std.Err & $\mathrm{Z}$ & $\mathrm{P}>|\mathrm{Z}|$ & 95\% CI \\
\hline Age & .032 & .006 & 4.96 & $<0.001$ & $.019 \sim .045$ \\
Periprocedural & .598 & .156 & 3.82 & $<0.001$ & $.291 \sim .905$ \\
bradycardia & & & & & \\
Using thrombus & .607 & .179 & 3.39 & 0.001 & $.256 \sim .958$ \\
aspiration devices & & & & & \\
during operation & & & & & \\
Total occlusion of the & .504 & .2 & 2.52 & 0.012 & $.112 \sim .896$ \\
culprit vessel & & & & & \\
Neutrophil percentage & .022 & .007 & 3.14 & 0.002 & $.008 \sim .035$ \\
Cons & -6.677 & .692 & -9.64 & $<0.001$ & $-8.034 \sim-5.32$ \\
\hline
\end{tabular}

\section{References}

[1] Kloner RA. The importance of no-reflow/microvascular obstruction in the STEMI patient. Eur Heart J. 2017. 38(47): 3511-3513.

[2] Ibáñez B, Heusch G, Ovize M, Van de Werf F. Evolving therapies for myocardial ischemia/reperfusion injury. J Am Coll Cardiol 2015;65:1454-71.

[3] de Waha S, Patel MR, Granger CB, et al. Relationship between microvascular obstruction and adverse events following primary percutaneous coronary intervention for ST-segment elevation myocardial infarction: an individual patient data pooled analysis from seven randomized trials. Eur Heart J. 2017. 38(47): 3502-3510.

[4] Ibanez B, James S, Agewall S, et al. 2017 ESC Guidelines for the management of acute myocardial infarction in patients 
medRxiv preprint doi: https://doi.org/10.1101/2020.05.29.20116665; this version posted June 17, 2020. The copyright holder for this preprint (which was not certified by peer review) is the author/funder, who has granted medRxiv a license to display the preprint in perpetuity.

It is made available under a CC-BY-NC 4.0 International license .

presenting with ST-segment elevation: The Task Force for the management of acute myocardial infarction in patients presenting with ST-segment elevation of the European Society of Cardiology (ESC). Eur Heart J, 2018,39(2):119-177.

[5] Niccoli G, Scalone G, Lerman A, Crea F. Coronary microvascular obstruction in acute myocardial infarction. Eur Heart J 2016;37:1024-33.

[6] Heusch G. Coronary microvascular obstruction: the new frontier in cardioprotection. Basic Res Cardiol, 2019,114(6):45.

[7] Thygesen K, Alpert JS, Jaffe AS, et al. Fourth universal definition of myocardial infarction (2018). Eur Heart J, 2019,40(3):237-269.

[8] Kusumoto FM, Schoenfeld MH, Barrett C, et al. 2018 ACC/AHA/HRS Guideline on the Evaluation and Management of Patients With Bradycardia and Cardiac Conduction Delay: A Report of the American College of Cardiology/American Heart Association Task Force on Clinical Practice Guidelines and the Heart Rhythm Society. Circulation. 2019. 140(8): e382-e482.

[9] Baran DA, Grines CL, Bailey S, et al. SCAI clinical expert consensus statement on the classification of cardiogenic shock: This document was endorsed by the American College of Cardiology (ACC), the American Heart Association (AHA), the Society of Critical Care Medicine (SCCM), and the Society of Thoracic Surgeons (STS) in April 2019. Catheter Cardiovasc Interv. 2019. 94(1): 29-37.

[10] Li Y, Lyu S. Risk Factors of Periprocedural Bradycardia during Primary Percutaneous Coronary Intervention in Patients with Acute ST-Elevation Myocardial Infarction. Cardiol Res Pract. 2019. 2019: 4184702.

[11] Ustinova EE, Schultz HD. Activation of cardiac vagal afferents in ischemia and reperfusion. Prostaglandins versus oxygenderived free radicals. Circ Res 1994;74:904-11.

[12] Campagna JA, Carter C. Clinical relevance of the Bezold-Jarisch reflex[J]. Anesthesiology, 2003,98(5):1250-1260.

[13] Fajar JK, Heriansyah T, Rohman MS. The predictors of no reflow phenomenon after percutaneous coronary intervention in patients with ST elevation myocardial infarction: A meta-analysis. Indian Heart J 2018;70 Suppl 3:S406-406S418.

[14] Kirma C, Izgi A, Dundar C, et al. Clinical and procedural predictors of no-reflow phenomenon after primary percutaneous coronary interventions: experience at a single center. Circ J 2008;72:716-21.

[15] Durante A, Camici PG. Novel insights into an "old" phenomenon: the no reflow. Int J Cardiol. 2015. 187: 273-80. 